\title{
Corporate citizenship in South African business education
}

\author{
R. Hamann*, L. van Duin, C. Appels, E. Taylor and E. Akor \\ UNISA Centre for Corporate Citizenship, \\ College of Economic and Management Sciences, PO Box 392, \\ UNISA 0003, Republic of South Africa \\ hamanr@unisa.ac.za
}

Received November 2005

\begin{abstract}
This paper seeks to enhance our understanding of the extent and manner in which corporate citizenship and related topics are taught to business students in South Africa. It argues that there are increasingly prominent drivers for integrating these topics in business education, but we know little about how South African business schools are responding. The methodology relies on a survey of business schools' websites, as well as two survey questionnaires, one of which was aimed at MBA coordinators, while the other targeted a range of "MBA stakeholders" consisting of recent MBA graduates and representatives from business, government, and civil society. The findings suggest that, though there are some proactive business schools, South African MBA programmes are generally still dominated by conventional notions of business success. Furthermore, there are important contradictions between the perceptions of MBA coordinators, on the one hand, and those of the MBA stakeholders, with the latter generally demanding more rigorous treatment of corporate citizenship issues. The overarching conclusion is that a more committed engagement of and by South African business schools is required on the need for integrating corporate citizenship in business education.
\end{abstract}

*To whom all correspondence should be addressed.

\section{Introduction}

Internationally, there is an increasing emphasis on the need for greater exposure to corporate citizenship or related concepts, such as business ethics or corporate social responsibility (CSR), in business education. Whereas there is an ongoing debate about the definition and usefulness of the term (e.g., Matten \& Crane, 2005), corporate citizenship is used here as an umbrella term broadly referring to the hope that business is willing and able to contribute to sustainable development. It refers to the expectation that if companies sincerely engage with stakeholders (Clarkson, 1995), if they assess and manage their social, environmental, and economic impacts (the so-called triple-bottom line Elkington, 1997), and if they channel some of their capacities for value creation and innovation towards developmental objectives, then these efforts will make decisive contributions to a better society (Hamann, 2006).

For a start, the growing emphasis on the need for corporate citizenship in business education relates to the recent spate of corporate governance scandals epitomised by cases such as Enron. These prompted Swanson and Frederick (2003) to ask, 'Are business schools silent partners in corporate crime?' They argue, 'The executive managers of the scandal-ridden firms and their partners in crime, some holding MBA degrees, may reflect an approach to business education that elevates narrow self-interest above broader values of community and corporate citizenship' (op cit.: 2425; see also Ghoshal, 2005). Following a concerted campaign to introduce corporate citizenship as an obligatory theme in business education, the USA-based MBA accreditation body, the Association to Advance Collegiate
Schools of Business (AACSB), eventually urged business schools 'to strengthen this vital part of the curriculum' (AACSB, 2004: 7).

A second driver calling for increased attention to corporate citizenship in business schools relates to the need for a proactive response by business to the opportunities and challenges of sustainable development from the local to the global level. Initiatives like the United Nations Global Compact, as well as many companies and business associations, such as the World Business Council for Sustainable Development, argue that business has a crucial role to play in achieving the Millennium Development Goals, for instance. There are also a range of initiatives that seek to integrate the challenges and opportunities related to sustainable development into business curricula, including the European Academy for Business in Society (EABIS) and the Aspen Institute in the USA.

Despite these incentives and initiatives, the response by business schools at an international level seems patchy. The AACSB argues, 'While many schools have initiated new ethics instruction, we must not fall into the trap of assuming the majority of students are adequately prepared to meet the ethical challenges of the modern work-place' (op cit.: 7). This assessment is borne out by recent international surveys of MBA students, which find that students increasingly value ethical and social issues as part of the curriculum, but assess their post-MBA increase in proficiency on these issues as low (CHE, 2004; GMAC, 2005).

Apart from the overarching challenge to convince business school deans of the need and value of corporate citizenship, 
there remains some confusion as to what it means and how it should be packaged. For instance, the field of business ethics has a long history of research and debate, with established professional bodies, dedicated journals, and international conferences and publications (e.g., Enderle, 1999). Usage of the term CSR also has a fairly long history (Carroll, 1999), particularly in North America. However, CSR and corporate citizenship have gained increasing prominence over the last decade in conjunction with the emphasis on sustainable development. The added impetus of the term sustainability relates to a growing awareness of the urgency and particular character of social and environmental challenges, including these challenges' international dimension, their interdisciplinary nature, and their complexity.

It is perhaps trite to attempt clear distinctions between terms such as business ethics and corporate citizenship, also because there is and should be so much overlap and crosspollination between them. However, for the purpose of assessing the current state of teaching and research on these issues, it is important to note that there are a variety of terms and concepts being used, that they denote different sets of emphases for different people, and that they can easily give rise to confusion, especially amongst those who are uncertain about their relevance to business education.

The picture is further complicated in the South African context. Not just business ethics and sustainable development are crucial imperatives, but so are socioeconomic transformation in the wake of apartheid and black economic empowerment (BEE). Crucial elements of BEE, including affirmative procurement, employee training, and community development, relate closely to the international corporate citizenship agenda. Indeed, this link ought to be developed more explicitly (Hamann, Azagbue, Kapelus \& Hein, 2005).

South African MBA programmes have recently undergone a rigorous re-accreditation process. This has resulted in a significant reduction of accredited programmes (19 out of an original 39 programmes, as of June 2005) and it has also provided an important window of opportunity for reconsidering the role of social issues in business education in South Africa. Significantly, corporate citizenship issues were included as part of the accreditation criteria, highlighting 'the opportunity for management education to contribute not only to the education of new managers but also to the shaping of society' (CHE, 2004:114). The accreditation report emphasises the importance of relevant research, which 'is especially needed in the context of developing countries, where the relationship between business and society takes specific forms... How many case studies are focusing on the ways in which black economic empowerment is advancing social objectives?' (op cit.:122). Over and above the various incentives for including corporate citizenship and related concepts in business education, there are different perspectives on how this should be done. A key issue in this regard is the extent to which corporate citizenship becomes part of the mainstream of business education, in order to enhance the likelihood of the average business student becoming aware of these issues. Moreover, there is a tension in this regard between three different options: the provision of elective, voluntary modules on CSR-related issues, the inclusion of compulsory CSR-related courses, and, finally, 'embedding' these issues in standard core modules, such as the business strategy component of an MBA (Matten \& Moon, 2004). Most would probably agree that a mix of strategies is important, though the challenge remains to provide more obligatory exposure to social issues and to ensure that embedded CSR topics are given sufficient weight and rigour (CHE, 2004). Another aspect of the methodology for teaching corporate citizenship that is widely agreed upon is the importance of case studies, particularly those with geographic relevance (op cit.; Barkhuysen \& Rossouw, 2000).

\section{Aim and research questions}

This research aims to enhance our understanding of the extent and manner in which corporate citizenship and related topics are taught to business students in South Africa. There are three objectives: First, to provide an overview of actual CSR-related content in South African MBA programmes; second, to compare this offering to the perceptions of MBA coordinators and various 'MBA stakeholders' comprising recent MBA graduates and representatives from business, government, and civil society; and third, to compare some of these findings to similar international surveys (bearing in mind, however, their disparate methodologies) (Aspen Institute / WRI, 2003, 2005; Matten \& Moon, 2004 - see Box 1 for a selection of these surveys' findings).

\section{Box 1: Selected results of international surveys of corporate citizenship in business education}

The Beyond Grey Pinstripes survey by the Aspen Institute and the World Resources Institute is conducted biannually and took place for the third time in 2005. In 2005, the sample included 600 invited full-time MBA programmes in six continents, whereby the only South African entrant is the Graduate School of Business at Stellenbosch University. Some of the key trends identified in these surveys are as follows (Aspen Institute / WRI, 2003; 2005):

- An increasing number of schools (54\% in 2005, up from $45 \%$ in 2003 and $34 \%$ in 2001) require one or more courses in ethics, CSR, sustainability, or business and society;

- Integration of social and environmental topics into other required courses - such as accounting, economics, finance, information technology, marketing, operations, and strategy - remains limited;

- The offering of electives with social or environmental content is increasing (with an increase of $70 \%$ from 2001 to 2003), though in the 2003 survey, there were only 40 relevant elective courses in the 100 schools sampled;

- In the 2005 survey, only $4 \%$ of faculty at the surveyed schools published research on social or environmental topics in leading peer-reviewed management journals. 
One of the most comprehensive, recent academic surveys on the integration of CSR in business education yielded responses from about 25\% of European business schools (Matten \& Moon, 2004). Bearing in mind the possible bias in the sample, the survey's findings included the following:

- $\quad$ There is a highly diverse understanding and packaging of CSR teaching. The most common label used for CSR-related modules is business ethics (35\%), followed by CSR (11\%) and environmental management (9\%);

- $12 \%$ of the surveyed schools include dedicated CSR programmes in their MBA, while 32\% offer optional CSR modules;

- $80 \%$ of surveyed schools describe themselves as mainstreaming CSR into their teaching programmes, whereby this is achieved by means of optional modules (47\%), embedding in other modules and courses (38\%), compulsory courses (27\%), and other teaching activities (e.g., seminars) (20\%);

- With regard to the use of special teaching tools, there is widespread use of practitioner speakers, be it from business, CSR industry or NGOs, as well as case studies from industry;

- $\quad$ The most important current drivers of CSR teaching in the surveyed business schools are individual faculty members and school leadership, whereas the most important perceived future drivers are business support and the inclusion of relevant criteria in accreditation and ranking procedures;

- Two-thirds of schools have staff active in CSR-related research and a quarter of schools provide $\mathrm{PhD}$ supervision in the field. One fifth of the schools have dedicated CSR research centres;

- $\quad$ By inference, the authors argue that there seems to be a strong interest in CSR among practitioners and industry.

Our focus is generally on South African MBA programmes, though some of the research questions deal more broadly with business education, which includes aspects such as research and executive courses. This focus on MBAs was considered important in order to allow for more targeted questions and an improved measure of comparability between respondents. MBAs are arguably the most prominent expression of business education and their curriculum is a powerful indicator of the extent and manner of mainstreaming of corporate citizenship issues.

There are five guiding research questions, inspired by Aspen Institute / WRI (2003) and Matten and Moon (2004):

1) In terms of corporate citizenship and related topics, what is being taught in South African MBA programmes, and in what form (i.e. as dedicated elective or obligatory courses, or embedded in other courses)?

2) How are these topics being taught in South African business schools, in terms of the level of specialisation of teaching staff and the teaching methods employed?

3) What are the key incentives or motivations for including these topics in business education, currently and in future?

4) What is the status of research on corporate citizenship or related topics in South African business schools?

5) What is the status of executive education on corporate citizenship or related topics in South African business schools?

\section{Methodology}

Data generation for this research relied on a survey of South African business schools' webpages and the dissemination of questionnaires. The internet-based survey only generated data of relatively limited scope and depth. However, it allowed the collection of information about each of the South African business schools that offer an accredited MBA. This is an important advantage, because it diminishes the bias that is likely to occur in questionnaire surveys (as in Matten \& Moon, 2004) or invited samples (as in the Beyond Grey Pinstripes surveys, Aspen / WRI, 2003; 2005). Furthermore, the internet survey and the questionnaires were used to corroborate each other's data.

So as to increase the scope and depth of the webpage survey, data generated by three teams working independently of each other on all of the available webpages were corroborated and collated. Only course content explicitly referring to aspects related to a selection of key terms relevant to corporate citizenship was deemed relevant. The key terms are: CSR or corporate citizenship (considered here to be synonymous), sustainable development, environmental management, business ethics, corporate governance, transformation / black economic empowerment, and gender.

The survey questionnaires were targeted at two key groups. The first consisted of the MBA coordinators or directors of the 17 South African business schools with fully accredited MBA programmes, as well as one further school with provisional accreditation (CHE, 2005). The second group consisted of a range of 'MBA stakeholders': recent MBA graduates, as well as representatives of business (mostly in CSR related positions), NGOs, and government.

The questions in both questionnaires cover the same issues corresponding to the research questions listed above though the emphasis in the MBA coordinators' questionnaire is on the actual content of CSR education, while the other questionnaire also queried perceptions about the desired or ideal content of CSR research and teaching in business schools. Box 2 provides the questionnaire disseminated to MBA coordinators. 
The purpose of these separate questionnaires was to assess and compare not just the perspectives of the MBA coordinators, but also the perspectives of other stakeholder groups. So, for instance, while Matten and Moon (2004:335) infer the 'strong interest in CSR among practitioners and industry' from the data generated from business schools' responses, this level of interest is explicitly examined in this survey with respect to a crosssection of MBA stakeholders.

\section{Box 2: Questionnaire for MBA coordinators}

1) For the following set of topics, please indicate the level of importance that they are currently given in your MBA programme. Please mark on a scale from 1 (not important) to 5 (most important). If possible, please elaborate in terms of the modules, assignments, or number of credits that cover these topics. Please also indicate whether these are compulsory or elective modules, or whether they are integrated in other components of the MBA.

- $\quad$ Corporate social responsibility or corporate citizenship

- $\quad$ Sustainable development

- Environmental management

- Business ethics

- Corporate governance

- $\quad$ Transformation / black economic empowerment

- $\quad$ Gender issues

- $\quad$ Other - please specify

2) If any of these issues are integrated in other components of your MBA, please indicate which components and how this integration is implemented.

3) Who teaches these modules - does this faculty have some level of specialisation in these topics? Please specify.

4) What are the most prominent teaching tools for these issues? Indicate on a scale from 1 (not prominent) to 5 (most prominent) with regard to the following:

- Invitation of speakers from business

- Invitation of speakers from other groups, such as government or labour

- $\quad$ Case studies

- Debates

- $\quad$ Presentations

- $\quad$ Essay assignments

- $\quad$ Other - please specify

5) What are the key incentives or motivations for including such issues in your MBA programme? Please assess the following on a scale from 1 (not important) to 5 (most important):

- Initiative by individual faculty members

- $\quad$ Mandate from school leadership

- Mandate from university leadership

- $\quad$ Business incentives or support
- $\quad$ Student demand

- Government incentives or regulations, including programme accreditation

- $\quad$ Other - please specify

6) Do you think these issues will become more prominent in your MBA in the future? Why?

7) Are faculty or students in your school conducting research in these areas? If yes, please specify.

8) Apart from MBA programmes, do you feel there is a sufficient offering of executive education on these topics in South Africa? Please indicate your response on a scale from 1 (not at all sufficient) to 5 (very sufficient). Please also mention any particular executive education programme that you may be aware of.

The MBA coordinators of the 18 business schools were phoned and asked to participate in the survey, and the questionnaire for MBA coordinators was then sent to them by email. Only one business school explicitly refused to participate. To date 10 responses have been received, representing eight business schools. Data from the questionnaire responses were augmented and corroborated with data from the web-based survey.

The questionnaire for MBA stakeholders was disseminated via four channels: First, many of the contacted MBA coordinators agreed to disseminate the relevant questionnaire to recent MBA graduates. Second, the questionnaire was disseminated through a mailing list of the National Business Initiative, consisting mostly of senior general or sustainability managers in 33 large companies, as well as 44 representatives from NGOs, consultancy companies, government, and research organizations. Third, the questionnaire was sent to the advisory council of the Unisa Centre for Corporate Citizenship, consisting of about 20 representatives of companies, mostly in CSR related positions. Finally, it was sent to a personal contact list comprising about 70 representatives of business (mostly in CSR related positions), NGOs, and government.

Out of an estimated total of between 300 and 500 MBA alumni and 150 other stakeholder groups, we received 25 responses. Apart from the MBA alumni, the dissemination method introduced a certain bias, in that many of the respondents have some prior interest in CSR and are thus likely to expect some exposure for such issues in business education.

\section{Results and discussion}

\section{What is being taught and in what form?}

Table 1 provides an overview of MBA curricula with relevance to corporate citizenship, based on the web-based survey. Mention is made of stand-alone courses or modules with titles relevant to corporate citizenship, as well as core courses, such as strategy, etc., in which explicit mention is made of issues related to corporate citizenship. 
Table 1: Overview of explicit MBA course offerings relevant to corporate citizenship

\begin{tabular}{|c|c|}
\hline School & Corporate citizenship content \\
\hline Damelin International College & No explicit reference. \\
\hline $\begin{array}{l}\text { Henley Management College of } \\
\text { SA }\end{array}$ & Elective on ‘corporate governance’ (out of a total of 15). \\
\hline $\begin{array}{l}\text { Management College of Southern } \\
\text { Africa }\end{array}$ & Core course on 'business and professional ethics’. \\
\hline Milpark Business School & No explicit reference. \\
\hline $\begin{array}{l}\text { Nelson Mandela Metropolitan } \\
\text { University }\end{array}$ & No explicit reference. \\
\hline $\begin{array}{l}\text { North-West University Mafikeng } \\
\text { Graduate School of Business and } \\
\text { Leadership }\end{array}$ & $\begin{array}{l}\text { Core courses on 'public enterprise and public / private partnership', 'managing international } \\
\text { development', and 'public management'. Specialisation on human resources management includes } \\
\text { module on 'transformation'. }\end{array}$ \\
\hline $\begin{array}{l}\text { North-West University } \\
\text { Potchefstroom Business School }\end{array}$ & An elective programme on 'strategic thinking' includes a module on 'power, politics, and ethics'. \\
\hline $\begin{array}{l}\text { Rhodes University Investec } \\
\text { Business School }\end{array}$ & $\begin{array}{l}\text { Core course on 'impact on society’. Specialisation in environmental management includes a variety of } \\
\text { environment oriented modules, such as ‘environmental sustainability principles for business leaders'. }\end{array}$ \\
\hline $\begin{array}{l}\text { Tshwane University of } \\
\text { Technology Business School }\end{array}$ & Elective on 'environmental management' (out of a total of six). \\
\hline $\begin{array}{l}\text { Unisa School of Business } \\
\text { Leadership }\end{array}$ & Core course on 'business ethics’. Elective on ‘corporate governance’ (out of a total of nine). \\
\hline $\begin{array}{l}\text { University of Cape Town } \\
\text { Graduate School of Business }\end{array}$ & $\begin{array}{l}\text { Core course 'Business, government, and society' including required reading and five lectures by guest } \\
\text { lecturer on 'business and sustainable development' including CSR, business case, sustainability } \\
\text { reporting and management, ethics and organisational integrity, and climate change. Electives on } \\
\text { 'CSR' and 'social entrepreneurship' (out of a total of 28). }\end{array}$ \\
\hline $\begin{array}{l}\text { University of Kwazulu-Natal } \\
\text { Graduate School of Business }\end{array}$ & No explicit reference. \\
\hline $\begin{array}{l}\text { University of Limpopo Graduate } \\
\text { School of Leadership }\end{array}$ & No explicit reference. \\
\hline $\begin{array}{l}\text { University of Pretoria Gordon } \\
\text { Institute of Business Science }\end{array}$ & $\begin{array}{l}\text { Core course on 'HIV/AIDS policy and strategy'. Electives on 'corporate governance' and 'business } \\
\text { ethics and values' (out of a total of 19). }\end{array}$ \\
\hline $\begin{array}{l}\text { University of Pretoria Graduate } \\
\text { School of Management }\end{array}$ & $\begin{array}{l}\text { Elective on 'environmental management' (out of a total of eight). Specialisation is possible in } \\
\text { ‘environmental business'. }\end{array}$ \\
\hline $\begin{array}{l}\text { University of Stellenbosch } \\
\text { Graduate School of Business }\end{array}$ & $\begin{array}{l}\text { Core course on 'business ethics'. Electives on 'strategic HIV/AIDS management' and 'NEPAD in } \\
\text { action' (out of a total of 29). }\end{array}$ \\
\hline $\begin{array}{l}\text { University of the Free State School } \\
\text { of Management }\end{array}$ & $\begin{array}{l}\text { Core component on ‘contemporary business issues' includes coverage of 'transformation' and } \\
\text { 'business ethics and values'. Electives on ‘corporate governance and ethics' and 'management of } \\
\text { HIV/AIDS' (out of a total of 14). }\end{array}$ \\
\hline $\begin{array}{l}\text { University of the Witwatersrand } \\
\text { Business School }\end{array}$ & $\begin{array}{l}\text { Electives on ‘corporate governance and control' and 'HIV/AIDS in the workplace' (out of a total of } \\
\text { 32). }\end{array}$ \\
\hline
\end{tabular}

Source: Business school websites

Table 1 illustrates, in summary:

- $\quad$ Only one business school (less than 1\%) includes a comprehensive, core module on corporate citizenship, which explicitly refers to social, environmental, and economic aspects of sustainability in an integrated fashion;

- $\quad$ Four schools include a core module on business ethics, while one school requires a course on impact on society' and another on 'HIV/AIDS policy and strategy'. In total, therefore, seven schools or just under $40 \%$ include some explicit required corporate citizenship content in their MBA curriculum;

- Seven schools offer electives on corporate governance, business ethics, or corporate responsibility, while three schools offer electives on environmental management, two schools on HIV/AIDS in the workplace, and one school on 'transformation'.
- $\quad$ Five schools or just under 30\% include no explicit reference to corporate citizenship themes whatsoever in their curricula.

These findings correspond roughly to the international situation. When compared to the Beyond Grey Pinstripes surveys, South African business schools lag behind the international trend to include obligatory courses on CSRrelated issues. Whereas less than $40 \%$ of South African MBAs currently require such a course, $45 \%$ and $54 \%$ of the Aspen Institute / WRI sample did so in 2003 and 2005, respectively (Aspen Institute / WRI, 2003; 2005). On the other hand, the South African findings compare more favourably with the European ones (Matten \& Moon, 2004). Similarly, with regard to the provision of elective courses, South African business schools seem to be generally on par with the Aspen / WRI sample, but provide greater options than the European sample (Matten \& Moon, 2004). However, the incidence of no explicit reference to corporate citizenship themes whatsoever seems particularly high in South Africa. 
It is apparent that the data represented in Table 1 is limited in that it relies predominantly on business school websites. Data from the questionnaire - particularly questions one and two - provide additional information on actual course content. Question one (see Box 2) requires an assessment of the importance of CSR-related topics, with the results showing three clusters:

- Business ethics and corporate governance received the highest scores, with 4.9 and 4.6, respectively.

- $\quad$ The next highest score was for BEE (4.2) and then for CSR (4).

- Gender obtained a score of 3.7 and sustainable development was the second-lowest scorer at 3.6. Environmental management scored 3.1.

Scores for CSR, sustainable development, and environmental management had the highest levels of variance, indicating high levels of disparity between MBA coordinators' assessments. This is especially pertinent in a comparison between CSR and BEE, both of which received similar scores, but the former showing much higher divergence in opinions (with a standard deviation of 1.5 as opposed to 0.9). This seems to suggest that there is little debate amongst MBA coordinators, nor is there a common platform for interaction on CSR-related issues.

In their survey of CSR education in Europe, Matten and Moon (2004) also identified business ethics as the most prominent title for CSR-related modules. However, they found that corporate governance was much less common. This illustrates the crucial importance and prominence of corporate governance in the South African business environment, based in particular on the second King Report on Corporate Governance in South Africa (King Committee on Corporate Governance, 2002). The other significant difference in the South African responses is obviously related to the prominence of BEE.

Importantly, MBA directors' assessment of the importance of CSR-related topics is different to that of the general stakeholder respondents. These respondents' scores can be summarised as follows:

- Sustainable development and CSR are the most important themes, both with a mean of about 4,6 .

- $\quad$ Business ethics and corporate governance received 4,3 and 4,2 , respectively.

- BEE, environmental management, and gender constitute the third group with scores between 3,5 and 3,8 .

As mentioned, the stakeholder sample represents a particular set of respondents who are likely to have an interest in sustainable development. Nevertheless, the results indicate that there are many MBA stakeholders - either in terms of students, employers, or interested parties - who clearly ascribe more value to sustainable development and CSR as themes for MBAs than do the MBA coordinators.
Furthermore, the stakeholders' responses all display lower levels of variance than those from MBA directors, which also suggests that this set of perceptions is widespread and more fully developed.

Table 1 fails to illustrate the extent or manner in which CSR themes are integrated into other core components of the MBAs, such as strategy or marketing, mostly because such integration was not referred to on any business school websites, bar one. This integration or embedding was the theme of the second questionnaire question. However, only few respondents answered this question, further suggesting that embedding CSR-related issues is not prominent. Furthermore, the actual extent or rigour of this embedding is difficult to assess in the absence of more detailed responses. For instance, one respondent argued that the business school in question integrates the various elements of corporate citizenship into the most relevant core components, such as marketing, economics, and organisational development. However, another representative from the same school argued, 'These issues are not really relevant to us.'

\section{How is it being taught?}

The third question in the questionnaire deals with the level of specialisation of those teaching corporate citizenship issues in the MBAs. Almost all MBA directors' responses indicated that teaching staff were suitably specialised in these issues, but this was rarely specified or elaborated upon. Notable exceptions include the use of expert guest lecturers in the sustainable development module at UCT and the HIV/AIDS module at the Gordon Institute of Business Science. Scepticism regarding faculty members' level of qualification in these matters is also evident in the MBA stakeholders' responses. On a scale of 0 (not qualified) to 5 (very qualified), the mean response is 2,4 , with a standard deviation of less than 0,9 . One respondent with close links to one of the better performing business schools noted as follows,

From my experience I do not think that there is nearly enough understanding amongst most core staff of the challenges and opportunities associated with sustainable development... I was quite amazed recently by the lack of knowledge of many of the various existing CSR tools and initiatives - almost none of the staff have heard of the Global Reporting Initiative, for instance.

With regard to the teaching tools used for CSR-related issues in MBA programmes, all of the suggested options in question four were given a high rating by MBA directors, the highest being for the use of essay assignments, invitation of business speakers, and case studies. This is broadly in line with European responses reported on by Matten and Moon (2004). Stakeholders' responses indicated a different emphasis, with by far the highest scores for case studies, followed by facilitated debates and invitation of business speakers. Some recommended other teaching methods, such as site visits or immersion programmes, in which students become involved in project management and problem solving. 


\section{Current and future drivers for integrating corporate citizenship in business education}

Questionnaire question five queried 'key incentives or motivations for including CSR-related issues in your MBA programme.' MBA directors identified the most important factor as being school leadership (4.7), thereby highlighting its importance in South Africa considering its second place after individual faculty members in the European study (Matten \& Moon, 2004). South African MBA coordinators identified as the second most important driver the demand and support for such topics from business (4.5), followed by individual faculty members (4.4), and student demand (4.3). Government and university leadership were seen as relatively weak drivers. The assessment of the role of government is perhaps surprising given the Council for Higher Education's emphasis on including corporate citizenship in MBA curricula (CHE, 2004). MBA stakeholders, on the other hand, put the driving role of government on a par with that of school leadership, individual faculty members, and business (4.0).

When asked whether CSR issues will become more prominent in MBAs in the future, all but one of the MBA directors responded positively. Some of the reasons given are as follows:

- 'Success of future business leadership will be determined by an understanding of these issues.'

- $\quad$ 'The university is an institution in a social context and has a duty to teach these subjects.'

- 'This is particularly relevant for the South African business environment and its focus on social development, which is essential for economic growth.'

The MBA coordinator who answered 'no' to this question argued that CSR-related issues are already adequately catered for.

The MBA stakeholders also argued that CSR-issues will become more prominent in future. The reasons given provide further indication of the sense that South African MBA programmes have some catching up to do:

- 'South Africa is falling behind the leaders in the academic world and must catch up.'

- 'We are academically at a very nascent phase in matters related to corporate responsibility... there is still a strong bias in our MBA syllabi towards the traditional single bottom-line approach.'

\section{The status of research in business schools}

MBA coordinators' responses to the question on CSRrelated research were generally non-committal. All but three respondents indicated that such research was being undertaken within the school, but were unable to elaborate. Most noted that some MBA students choose CSR-related topics in their essays or dissertations, while two respondents could point to faculty members conducting relevant research, with an emphasis on BEE related issues and social marketing. This situation differs from the findings of the European survey, in which two-thirds of respondents indicated that business school staff are engaged in CSR research (though bear in mind the likely bias in that sample) (Matten \& Moon, 2004).

In contrast to South African MBA coordinators' perceptions, almost all MBA stakeholders argued that insufficient CSR-related research is conducted in business schools. As noted by one business manager: 'I am not aware of any significant research into sustainable development issues in South Africa... no results are visible.' A CEO of a prominent NGO noted, 'If business schools are [conducting such research], it doesn't show.'

\section{The status of executive education on corporate citizenship}

When asked whether there is a sufficient offering of executive courses on CSR-related issues, almost all MBA directors argued that existing courses are insufficient. Only one respondent mentioned a particular programme, focused on BEE. Not only does this illustrate that South African business schools generally have a limited offering of executive courses on CSR-related issues, but MBA directors also have a generally low awareness of the various executive courses that are in fact on offer. Table 2 provides a brief overview of some of these programmes in the fields of corporate citizenship, corporate governance, and business ethics, with an emphasis on those courses targeted at business managers.

MBA stakeholders concurred that there are insufficient executive courses on CSR-related issues. However, these respondents generally had a higher awareness of existing courses, with about half of them pointing out some of the courses or organisations listed in Table 2.

\section{Conclusions}

This research sought to enhance our understanding of the extent and manner in which corporate citizenship and related topics are taught to business students in South Africa. The findings suggest that, though there are some leading business schools that have a more proactive response to international and national drivers for integrating CSR-related topics, South African MBA programmes are generally still dominated by conventional notions of business success. In this regard, South Africa is broadly in line with international trends, especially in Europe (Matten \& Moon, 2004), though it lags the trend apparent in the Beyond Grey Pinstripes samples (Aspen Institute / WRI, 2003; 2005). 
Table 2: Selected executive programmes or dedicated institutes relevant to CSR or related topics

\begin{tabular}{|c|c|}
\hline School or institute & Overview \\
\hline $\begin{array}{l}\text { Cambridge } \\
\text { Programme for } \\
\text { Industry (CPI) }\end{array}$ & $\begin{array}{l}\text { The CPI runs two annual week-long } \\
\text { seminar programmes on sustainability for } \\
\text { business: the Prince of Wales Business } \\
\text { and Environment Programme targets } \\
\text { senior executives and the Cambridge } \\
\text { Sustainability Practitioners Seminar is } \\
\text { aimed at senior managers with } \\
\text { responsibilities for sustainable } \\
\text { development. }\end{array}$ \\
\hline $\begin{array}{l}\text { Gordon Institute of } \\
\text { Business Sciences } \\
\text { (GIBS) (University of } \\
\text { Pretoria) }\end{array}$ & $\begin{array}{l}\text { GIBS offers (together with Harvard } \\
\text { Business School) a one-week programme } \\
\text { on Making Markets Work, focused on the } \\
\text { relationship between companies and } \\
\text { government in governance for sustainable } \\
\text { development. GIBS also offers a variety } \\
\text { of other short courses on topics such as } \\
\text { BEE. }\end{array}$ \\
\hline Institut & $\begin{array}{l}\text { The institute offers a number of courses } \\
\text { for directors' development, one of which } \\
\text { focuses on corporate governance. }\end{array}$ \\
\hline $\begin{array}{l}\text { Leadership Centre at } \\
\text { the University of } \\
\text { Kwazulu-Natal }\end{array}$ & $\begin{array}{l}\text { Over and above a Masters programme in } \\
\text { corporate citizenship, the centre also } \\
\text { offers a variety of short courses (this } \\
\text { offering is currently being updated). }\end{array}$ \\
\hline $\begin{array}{l}\text { Sustainability } \\
\text { Institute (University } \\
\text { of Stellenbosch) }\end{array}$ & $\begin{array}{l}\text { The institute offers an annual one-week } \\
\text { course on corporate citizenship. This is } \\
\text { part of a Masters degree in Sustainable } \\
\text { Development Planning, but can also be } \\
\text { attended as executive student. A number } \\
\text { of other modules are also relevant. }\end{array}$ \\
\hline $\begin{array}{l}\text { UCT Graduate School } \\
\text { of Business }\end{array}$ & $\begin{array}{l}\text { The school includes the Centre for } \\
\text { Innovation and Enterpreneurship, as well } \\
\text { as the Centre for Leadership and Public } \\
\text { Values. The school also offers a variety } \\
\text { of relevant short courses on topics such as } \\
\text { business ethics and BEE. }\end{array}$ \\
\hline $\begin{array}{l}\text { Unisa Centre for } \\
\text { Corporate Citizenship }\end{array}$ & $\begin{array}{l}\text { The Centre offers two 6-month courses } \\
\text { on corporate citizenship and corporate } \\
\text { governance, as well as seven short } \\
\text { courses of two or three days' duration, } \\
\text { focusing on issues such as stakeholder } \\
\text { engagement or responsible tourism. }\end{array}$ \\
\hline $\begin{array}{l}\text { University of Pretoria } \\
\text { Graduate School of } \\
\text { Management }\end{array}$ & $\begin{array}{l}\text { The Centre for Business and Professional } \\
\text { Ethics offers a Masters in workplace } \\
\text { ethics, as well as a number of short } \\
\text { courses. The school also includes a } \\
\text { Centre for Pro-poor Banking. }\end{array}$ \\
\hline
\end{tabular}

This research supports the findings of the Council for Higher Education (CHE, 2004) that South African MBAs tend to give a certain amount of prominence to particular South African themes, such as BEE. Corporate governance is also a theme that is more prominent in South African business schools than in Europe, probably due to the impact of the second King report. The topics sustainable development and CSR, on the other hand, are much less broadly recognised as important by MBA coordinators, with responses displaying a high degree of variance. This suggests that these themes have not featured prominently in debates related to MBA curricula in South Africa.

In contrast, there is a significant group of MBA stakeholders, comprising recent $\mathrm{MBA}$ graduates and representatives from business, government, and civil society, who value sustainable development and CSR much more highly and consistently than the MBA coordinators. This gap in perceptions is probably one of the most important findings of this research.

This gap is also evident with regard to other aspects of CSR education in business schools. For instance, MBA coordinators felt that members of business school faculty were well qualified to teach CSR-related subjects, while almost all MBA stakeholders contradicted this claim. A similar contradiction is also evident in the different groups' assessment of research undertaken in business schools. These contradictions also suggest that we ought to treat with caution MBA coordinators' assertions that CSR-themes are embedded in standard core modules, such as strategy or marketing.

The overarching conclusion is that a more committed engagement of and by South African business schools' leadership and faculty members is required on the need for integrating corporate citizenship in business education.

\section{Acknowledgements}

We are grateful to Jeremy Moon for sending us the questionnaire used in research conducted by the International Centre for Corporate Social Responsibility, Nottingham University Business School, in conjunction with EABIS, the European Foundation for Management Development, and the UN Global Compact (Matten \& Moon, 2004) - it provided important inspiration. Thank you also to the National Business Initiative for help with the dissemination of our questionnaire. This research was funded by the Unisa Centre for Corporate Citizenship and supported by the African Institute of Corporate Citizenship.

\section{References}

AACSB (Association to Advance Collegiate Schools of Business). 2004. Ethics education in business schools: Report of the Ethics Education Task Force. Tampa, FL: AACSB.

Aspen Institute / WRI (World Resources Institute). 2003. 'Beyond Grey Pinstripes 2003: Preparing MBAs for social and environmental stewardship'. [online]URL: www.beyondgreypinstripes.org. Accessed July 2005.

Aspen Institute / WRI (World Resources Institute). 2005. 'Beyond Grey Pinstripes 2005: Preparing MBAs for social and environmental stewardship'. [online] URL: www.beyondgreypinstripes.org. Accessed March 2006.

Barkhuysen, B. \& Rossouw, G.J. 2000. 'Business ethics as academic field in Africa: Its current status', Business Ethics: A European Review, 9(4):229-235.

Carroll, A.B. 1999. 'Corporate social responsibility: Evolution of a definitional construct', Business \& Society, 38(3): 268-95. 
CHE (Council for Higher Education). 2004. State of the provision of the MBA in South Africa. Pretoria: Council for Higher Education.

CHE (Council for Higher Education). 2005. MBA Press Release 30 June 2005.

Clarkson, M.B.E. 1995. 'A stakeholder framework for analysing and evaluating corporate social performance', Academy of Management Review, 20(1):92-117.

Elkington, J. 1997. Cannibals with forks: The triple bottom line of sustainable development. Oxford: Capstone.

Enderle, G. (Ed.). 1999. International business ethics: Challenges and approaches. Notre Dame: The University of Notre Dame Press.

Ghoshal, S. 2005. 'Bad management theories are destroying good management practices', Academy of Management Learning \& Education, 4(1):75-91.

GMAC (Graduate Management Admission Council). 2005. Global MBA graduate survey. McLean: GMAC. [online] URL: www.gmac.com. Accessed July 2005.

Hamann, R. 2006. 'Can business make decisive contributions to development? Towards a research agenda on corporate citizenship and beyond,' Development Southern Africa, 23(2):1-21.

Hamann, R., Azagbue, T., Kapelus, P. \& Hein, A. 2005. 'Universalising corporate social responsibility? South African challenges to the International Organization for Standardization's new social responsibility standard', Business and Society Review, 110(1):1-19.

King Committee on Corporate Governance. 2002. King Report on corporate governance for South Africa 2002. Johannesburg: Institute of Directors.

Matten, D. \& Crane, A. 2005. 'Corporate citizenship: Towards an extended theoretical conceptualization', Academy of Management Review, 30(1): 166-179.

Matten, D. \& Moon, J. 2004. 'Corporate social responsibility education in Europe', Journal of Business Ethics, 54: 323-337.

Swanson, D.L. \& Frederick, W.C. 2003. 'Are business schools silent partners in corporate crime?' Journal of Corporate Citizenship, 9(1): 24-27. 